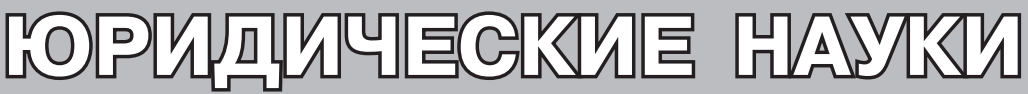

\section{Становмение и развитие пенитенциарных учреждений Екатеринодара (вторая помовина XIX - начамо XX вв.)}

\author{
И. Л. ИЗЮМСКАЯ \\ Правовое управление ФСИН России, г. Москва, Российская Федерация \\ ORCID: https://orcid.org/0000-0002-8823-7592, e-mail: rochka1919@rambler.ru
}

Р е фер а т

Введение: в статье рассмотрены предпосылки зарождения тюремных учреждений на Кубани, особенности их становления в Екатеринодаре - центре Кубанской области, образованной в 1860 г. На основе осмысления современного состояния изученности проблемы и анализа архивных материалов показано влияние государственно-правовых реформ 1860-1870-х гг. на строительство новых и расширение действующих тюремных учреждений, изучены условия содержания в них заключенных, раскрыта роль Екатеринодарского войскового тюремного комитета Общества попечительного о тюрьмах в развитии пенитенциарных учреждений Екатеринодара в таких приоритетных направлениях деятельности, как устройство мест заключения и обеспечение необходимого режима содержания, контроль за обеспечением бытовых условий арестантов, улучшение медицинского обслуживания арестантов и пр. Цель: отразить особенности развития пенитенциарных учреждений в целом на Кубани и в Екатеринодаре в частности. Методологическую основу исследования составляют философские, общенаучные и частнонаучные методы (диалектический, системно-структурный, историко-генетический, сравнительный, формально-юридический и др.). Обсуждение: в статье на основе краткого анализа работ Н. И. Галкиной, Н. В. Славинского, М. К. Батчаевой, С. А. Лобовой и др., затрагивающих исследуемую проблематику, а также изучения материалов, содержащихся в фондах Государственного архива Краснодарского края, освещаются вопросы становления и эволюции тюремных учреждений на Кубани в рассматриваемых хронологических рамках. Результаты: в связи с получением в 1867 г. Екатеринодаром статуса гражданского города произошло резкое увеличение приезжего населения, что повлекло рост количества преступлений и, соответственно, числа лиц, отбывающих наказание в виде лишения свободы. Данное обстоятельство явилось причиной расширения действующих тюремных учреждений и строительства новых, в частности Екатеринодарской областной тюрьмы. В связи с образованием в 1867 г. Екатеринодарского войскового тюремного комитета Общества попечительного о тюрьмах, в чьем ведении находились все пенитенциарные учреждения Кубани, удалось достичь определенных успехов в деле тюремного попечительства в рамках своей компетенции. Развитие попечительства по отношению к заключенным следует считать одним из механизмов, решавших задачу улучшения положения арестантов. Финансовую основу этой деятельности составляли казенные и частные благотворительные средства. Также отмечается, что для тюрем Кубани остро стояли проблемы, присущие всей пенитенциарной системе: недостаточное финансирование, неприспособленность тюремных помещений (переполненность), тяжелые условия содержания.

К л юч е в ы е с л о в а : Кубанская область; Екатеринодар; места заключения Кубани; Екатеринодарский войсковой острог; Екатеринодарская областная тюрьма; 
Екатеринодарский тюремный комитет; тюремное попечительство; финансирование тюрем.

12.00.01 - Теория и история права и государства; история учений о праве и государстве.

Д ля ц и ти ров ан ия: Изюмская И. Л. Становление и развитие пенитенциарных учреждений Екатеринодара (вторая половина XIX - начало XXвв.). Пенитенциарная наука, 2021, т. 15, № 4 (56), с. 697-708. DOI 10.46741/2686-9764-2021-15-4-697-708.

\title{
Formation and Development of Penitentiary Institutions in Yekaterinodar (Second Half of the 19th-Early 20th Centuries)
}

\author{
IRINA L. IZYUMSKAYA \\ Law Department of the Federal Penitentiary Service of Russia, Moscow, Russian Federation \\ ORCID: https://orcid.org/0000-0002-8823-7592, e-mail: rochka1919@rambler.ru
}

\begin{abstract}
Introduction: the article is devoted to the historic background of the prison system in the Kuban and features of the prison institutions formation in Yekaterinodar - the center of the Kuban Oblast, formed in 1860. The article, based on the comprehension of historical experience and analysis of archival materials, shows the impact of the 18601870 state-legal reforms on construction of new and enlargement of current prisons and studies the specifics of prisoner detention conditions. It reveals the role of the Yekaterinodar Military Prison Committee "Prisons Custody Society" in enhancement of Yekaterinodar's penitentiary institutions: organization of places of detention and provision of the necessary detention regime; control over detainee's welfare; improvement of medical care for prisoners, etc. Purpose: to reflect development features of penitentiary institutions in the Kuban as a whole and Yekaterinodar in particular. The methodological basis of the research consists of philosophical, general scientific and private scientific methods (dialectical, system-structural, historical-genetic, comparative, formal-legal, etc.). Discussion: based on a brief analysis of the works of N.I. Galkina, N.V. Slavinskii, M.K. Batchayeva, S.A. Lobova, etc., devoted to the issues under consideration, as well as the study of materials contained in the funds of the State Archive of Krasnodar Territory, the author presents chronological background of formation and development of the Kuban prison institutions. As a result of the conducted research, the researcher comes to the following conclusion: since Yekaterinodar acquired the status of a civil city in 1867, there was a sharp increase in out-of-town visitors, which led to a rise in the number of crimes and, accordingly, persons serving sentences in the form of imprisonment. It involved the expansion of existing prison facilities and construction of new ones, in particular, the Yekaterinodar regional prison in 1876. The establishment of the Yekaterinodar Military Prison Committee "Prisons Custody Society" in 1867, which was in charge of the entire Kuban penitentiary system, helped achieve some success in prison guardianship within its competence. The development of guardianship in relation to prisoners should be considered one of the mechanisms that solved the problem of improving prisoners' situation. This activity was financed by state and private charitable funds. The author also notes that the Kuban prisons addressed acute problems, characteristic, however, of the entire penitentiary system, such as insufficient funding of prison facilities, unsuitability of prison facilities, i.e. overcrowding, and harsh detention conditions.

Keywords: Kuban Oblast; Yekaterinodar; places of detention in the Kuban; Yekaterinodar military prison; Yekaterinodar regional prison; Yekaterinodar Prison Committee; prison guardianship; prison financing.
\end{abstract}

12.00.01 - Theory and history of the law and state; history of the law and state studies.

For citation: Izyumskaya I. L. Formation and Development of Penitentiary Institutions in Yekaterinodar (Second Half of the 19th-Early 20th Centuries). Penitentiary Science, 2021, vol. 15, no. 4 (56), pp. 697-708. DOI 10.46741/2686-9764-2021-15-4-697708. 
Региональные аспекты развития пенитенциарных учреждений отражают общую специфику развития уголовно-исполнительной системы России. В этой связи представляется важным обратиться к истории пенитенциарных учреждений Кубани по второй половине XIX - начале XX вв.

Основные аспекты функционирования тюремных учреждений России этого периода получили отражение в работах дореволюционных ученых и публицистов, таких как А. А. Пионтоковский [14], Н. А. Таганцев [19], С. В. Познышев [15], И. Я. Фойницкий [21] Д. В. Краинский [6], В. Н. Никитин [10] и др.

В советский период наиболее значимым исследованием по истории царских тюрем в рассматриваемых хронологических рамках стал труд М. Н. Гернета [3], в котором не только описаны тюремные заведения и содержавшийся в них контингент, но и детально проанализировано отечественное пенитенциарное законодательство.

В числе постсоветских авторов, обращавшихся к данной теме, следует назвать А. В. Печникова [13], Л. П. Рассказова [17], И. В. Упорова [20] и др. Особо хотелось бы выделить комплексное исследование И. В. Упорова, в котором предпринята попытка историко-правового анализа формирования и реализации в России пенитенциарной политики.

Применительно к рассматриваемому в данной статье региону заслуживают внимания работы таких современных авторов, как Н. И. Галкина [2], Н. В. Славинский [18], М. К. Батчаева [1], С. А. Лобова [7] и др.

На основе изучения нормативных актов, архивных материалов и документов, теоретических подходов и выводов историкоправовой науки Н. И. Галкина в своем диссертационном исследовании установила закономерности осуществления тюремнопопечительной деятельности в Российской империи и ее особенности на Кубани для обоснования возможностей использования данного исторического опыта в современных условиях [2].

В диссертационном исследовании Н. В. Славинского прослежены пути становления, развития, правового регулирования и деятельности губернских тюремных инспекций в дореволюционной России и на Кубани [18].

Работа М. К. Батчаевой посвящена истории возникновения и функционирования благотворительно-тюремных комитетов на Ставрополье и Кубани во второй половине XIX - начале XX вв. в контексте эволюции отечественной пенитенциарной системы и деятельности российских тюремно-попечительских обществ [1].

С. А. Лобова исследует причины появления Екатеринодарского войскового тюремного комитета, его задачи и основные направления деятельности. Специфику деятельности этого тюремного комитета исследователь усматривает в том, что все дела по хозяйственному управлению местами заключения и исправлению заключенных были отнесены к его компетенции, причем в ведении комитета находились только места заключения, находящиеся в городе. Войсковые остроги (тюрьмы) содержались за счет Кубанского казачьего войска, городские финансировались из бюджета города, а станичные - из средств местных обществ, содержание же арестантов в тюрьмах обеспечивали Кубанское казачье войско, Государственное казначейство и Военное министерство [7].

В статье П. И. Остапенко и И. В. Сирицы подробно воссоздана история Екатеринодарской областной тюрьмы (1876-2007), в настоящее время функционирующей в качестве СИЗО-1 г. Краснодара [12].

Источниковую базу статьи образовали опубликованные законодательные документы, регламентировавшие на уровне государства во второй половине XIX - начале XX вв. деятельность тюремных учреждений и касавшиеся вопросов тюремной благотворительности, а также неопубликованные материалы из Государственного архива Краснодарского края (ГАКК, г. Краснодар), многие из которых ранее не привлекались к изучению. В ГАКК автором статьи проанализированы материалы следующих фондов: 454 «Канцелярия начальника Кубанской области и наказного атамана Кубанского казачьего войска, г. Екатеринодар, 1870-1917 гг.», 657 «Кубанская областная тюремная инспекция Главного областного тюремного управления, г. Екатеринодар Кубанской области, 1909-1920 гг.».

Пенитенциарные учреждения Кубани стали динамично развиваться с ростом казачьего региона. Законодательной основой для этого стали Учреждения для управления губерний Всероссийской империи от 7 ноября 1775 г. Организация исполнения 
наказания в виде лишения свободы относилась к кругу многочисленных обязанностей Войскового правления. Учреждениями предусматривалось создание губернских тюрем во главе со смотрителем из полицейских чинов. На Кубани они «трансформировались в войсковые остроги с режимом сословного разделения заключенных. Общее руководство всей тюремной системы в Черноморском казачьем войске замыкалось на войсковом атамане» [8, с. 12-13].

В первой половине XIX в. принимается ряд правовых актов, содержащих нормы о порядке и условиях реализации различных видов лишения свободы. Среди них необходимо выделить Инструкцию смотрителю губернского тюремного замка (1831), Свод учреждений и уставов содержащихся под стражею (1832), нормы которого распространялись только на гражданских лиц, и Уложение о наказаниях уголовных и исправительных (1845). Данные правовые акты были направлены на законодательное развитие института лишения свободы.

8 февраля 1860 г. была образована Кубанская область. В итоге этих преобразований Екатеринодар стал центром Кубанской области, возглавляемой «наказным атаманом Кубанского казачьего войска» [11, с. 20-21]. Согласно сведениям из описания Екатеринодара, составленного городским полицмейстером в 1861 г., в городе проживали жители преимущественно «черноморского казачьего сословия, без исключения малороссы. Нравы жителей города непредосудительны» [4, с. 122-122]. Согласно утвержденному 1 мая 1867 г. положению «О заселении и управлении города Екатеринодара» было разрешено поселение в нем всех желающих [4, с. 132]. Это означало, что город получил гражданский статус. В связи с переходом из войскового ведомства в гражданское утверждались правила заселения и управления. С сентября 1868 г. разрешалось русским подданным, которые не относились к войсковому сословию, поселяться и приобретать землю из земельных угодий казачьих войск, после чего поток переселенцев на Кубань, в том числе в Екатеринодар, резко возрос [4, с. 137].

Активное заселение территории Кубани и ее центра - Екатеринодара, безусловно, сказывалось на росте количества совершаемых преступлений и увеличении тюремного населения. Существенное влияние на развитие тюремной системы оказала кре- стьянская реформа 1861 г., в результате которой многие из крестьян покинули свое постоянное место жительства и стали заселять города. Зачастую не справляясь с непривычными для них городскими условиями, они пополняли ряды потенциальных преступников. Не был в этом плане исключением и Екатеринодар.

В рассматриваемый период институт лишения свободы представлялся весьма сложным, поскольку исполнение данного наказания осуществлялось в различных видах мест заключения (тюрьмах общего назначения, каторжных тюрьмах, смирительных домах, арестных помещениях, крепостях и др.). Для Екатеринодара «основными местами заключения являлись: войсковой острог, крепостной женский острожек, городская тюрьма при полицейском участке («полицейская тюрьма») и главная гауптвахта» [7, с. 292]. «Маловажные арестанты из гражданских лиц содержались в Екатеринодарской городской тюрьме. Сюда же переводили заключенных из острога в случае переполнения последнего. Размещалась она в здании городского полицейского управления, арендуемого у частного лица» [9, с. 140].

Исторические данные свидетельствуют о том, что тюремные учреждения Екатеринодара были переполнены, при этом помещения, в которых содержались заключенные, находились в весьма плачевном состоянии. Существующие места заключения не могли в полном объеме справиться с растущим количеством заключенных.

Екатеринодарский войсковой острог являлся главной тюрьмой Кубани. Находился тюремный замок (так иногда называли войсковой острог) на площади, где осуществлялись смотры войск и их разводы, и был окружен высокими и толстыми сваями [4, с. 124]. Решение о строительстве нового кирпичного острога было принято 11 мая 1817 г., и эксплуатировался он вплоть до лета 1876 г.

Необходимо отметить, что вскоре после отмены крепостного права перед государством встал вопрос о расширении количества тюремных учреждений, поскольку действующая тюремная система в рассматриваемый период не могла уже справляться со все возрастающей массой заключенных и испытывала значительные трудности в организации исполнения наказания в виде лишения свободы. В частности, материально-техническая база пенитенциарных уч- 
реждений оценивалась крайне неудовлетворительно [21, с. 49].

В связи с этим в 1862 г. от всех губернаторов Министерством внутренних дел были запрошены сведения о состоянии мест лишения свободы. Из полученных ответов было видно, что «за редчайшими исключениями тюрьмы находились в самом ужасном состоянии» [5, с. 49].

Следует согласиться с отечественными исследователями в том, что «проведенное особой комиссией Министерства внутренних дел обследование российских тюрем можно считать первым серьезным подходом к реформированию мест лишения свободы» [16, с. 187].

Обследования, которые стали регулярными с начала 1860-х гг., обнаруживали плохое состояние тюрем, что объяснялось практически полным отсутствием финансирования их строительства и ремонта со стороны государства.

Содержание в тюрьмах заключенныхбыло обеспечено «соответствующим ведомством (государственная казна, Кубанское войско или военное ведомство)» [9, с. 139]. Содержание Екатеринодарской войсковой тюрьмы осуществлялось в основном за счет Кубанского казачьего войска.

В 1867 г. был образован Екатеринодарский войсковой тюремный комитет Общества попечительного о тюрьмах (далее тюремный комитет), к которому перешло решение хозяйственных задач в местах лишения свободы, располагавшихся в черте города. Вновь созданному тюремному комитету предстояло заняться решением проблем неудовлетворительного финансирования тюремных учреждений, медицинского обеспечения арестантов и др. Улучшение условий содержания заключенных было главенствующим направлением в части реализации благотворительной функции.

Сведения о расходах на содержание тюрем заслуживают особого внимания. Архивные материалы свидетельствуют о том, что тюремный комитет в первую очередь направлял средства на улучшение питания арестантов. Так, «в июне 1868 г. на питание арестанта-чиновника, содержащегося в войсковом остроге, отпускалось 20 коп., обер-офицеру - 12 коп., "безчиновному" дворянину - 10 коп., "разночинцу" - 6 коп. в день» [7, с. 293]. К слову, продукты в то время в Екатеринодаре стоили очень дешево, и «расход в 16 копеек считался значитель- ным». На базаре большого карпа можно было купить за 5 коп., фунт (400 гр.) баранины - за 3 коп. [4, с. 124]. Следует отметить, что пищевой рацион арестантов мало чем отличался от традиционных продуктов для обеда горожан. Так, в одном из отчетов Кубанского областного правления за 1879 г. указывалось, что в пищу арестантам даются «мясные щи с зеленью» (ГАКК. Ф. 454. Оп. 7. Д. 1388. Л. 1-1 об.). В иных отчетах проверяющие отмечали, что «пища и хлеб вполне доброкачественны» (ГАКК. Ф. 657. Оп. 1. Д. 3. Л. 45). Полагаем, что обеспечение заключенных питанием было удовлетворительным.

Тюремный комитет уделял внимание вопросам обеспечения заключенных одеждой и бельем. Содержащимся в тюрьме одежда выдавалась при необходимости, а постельные принадлежности - в обязательном порядке. Так, «в марте 1868 г. на одежду и белье для арестантов войскового сословия и гражданского ведомства было потрачено около 500 рублей, а в феврале 1870 г. Войсковое правление направило в бюджет тюремного комитета 1 тыс. руб. для приобретения обуви и одежды арестантам войскового сословия в течение 1870 года» [7, с. 293].

Улучшение арестантского быта - не единственное направление благотворительной деятельности тюремного комитета. Одной из важных составляющих его работы было выделение средств для оказания помощи в воспитании детей (ГАКК. Ф. 461. Оп. 1. Д. 615. Л. 5). Кроме того, комитет осуществлял благотворительную деятельность и за пределами Кубанской области. Ярким примером является дело тюремного комитета о деньгах, выделенных в качестве пожертвований в пользу Общества попечения о семьях ссыльнокаторжных в Санкт-Петербурге (ГАКК. Ф. 461. Оп. 1. Д. 957. Л. 1).

Вопросы отопления и освещения острога не оставались без внимания тюремного комитета. Поскольку в Екатеринодаре электрическое освещение появилось лишь к 1894 г., то освещение острога, как и всех остальных зданий в городе, осуществлялось керосиновыми фонарями, на что направлялись достаточно большие средства. Так, «В 1871 г. Войсковым хозяйственным правлением на освещение острога было выделено почти 600 руб.» [7, с. 293]. Для сравнения: на освещение в ночное время всего города 200 керосиновыми фонаря- 
ми из «городских средств» тратилось 2 тыс. руб. [4, с. 150].

Вопросы материального обеспечения тюремных служителей также всегда оставались актуальными для тюремного комитета. Так, «согласно "Требовательной ведомости об отпуске содержания чинам, служившим при Екатеринодарском войсковом остроге с 1 января 1869 г. по 1 января 1870 г.", смотритель острога получал жалованье 557 руб. 14 коп.; писарь острога - 40 руб. 66 коп.; двое урядников - по 10 руб. 01 коп. каждому; казаки в количестве 21 человека - по 8 руб. 66 коп. каждому» [19, с. 293]. Цена на рабочие руки в городе составляла в день: поденщик - 50-60 коп., поденщица - 4045 коп. [4, с. 122-122]. Через пару лет тюремным служителям почти в два раза было повышено жалование (ГАКК. Ф. 461. Оп. 1. Д. 181. Л. 2-3). Данный факт свидетельствует о формировании определенных гарантий социальной защищенности сотрудников пенитенциарных учреждений со стороны государства.

Вопросы обустройства войскового острога также не оставались без внимания. Так, уже в 1866 г. был отстроен при войсковом остроге каменный под железной крышей карцер для помещения «более важных преступников». 20 июня 1870 г. Войсковое правление сообщило в тюремный комитет, что «капитальная ремонтировка здания острога, начатая Войсковым Архитектором с октября месяца прошлого года, по утвержденной для того в Окружном Инженерном Управлении Кавказского военного округа смете на сумму 3493 руб., должна окончиться к 15 сентября 1870 года» (ГАКК. Ф. 461. Оп. 1. Д. 113. Л. 12). В 1871 г. в остроге было «произведено ремонтное исправление зданий на сумму 1583 рублей» [7, с. 293].

Вместе с тем, несмотря на активную благотворительную деятельность тюремного комитета, решить проблему неудовлетворительного состояния тюрем объективно было нереально, что объяснялось общей нехваткой финансовых средств.

Кроме неудовлетворительных бытовых условий содержания осужденных в литературе отмечаются проблемы с «персоналом учреждений, поскольку еще не было выработано даже общих подходов к решению кадровых вопросов» [16, с. 182].

Начальник Кубанской области осуществлял за тюремными учреждениями надзорные функции общего характера. Не- посредственное же управление местами заключения находилось в руках тюремных смотрителей, в обязанности которых входили надзор за соблюдением арестантами чистоты, порядка, праведности и забота об исправлении нравственности преступников, основанном на нормах религии. Для этой же цели священники обязаны были отправлять религиозные обряды для заключенных, совершать исповеди.

Осужденным к заключению в тюрьме разрешались свидания с родственниками. Тюремные смотрители при этом тщательно следили за порядком организации свиданий. Так, в январе 1868 г. Екатеринодарским войсковым комитетом было объявлено, что «лица, прибывающие на свидание, принимаются смотрителем острога исключительно в воскресные и праздничные дни за час до обеда, а прибывшие позже установленного времени будут лишены права на свидание» (ГАКК. Ф. 461. Оп. 1. Д. 3. Л. 15). Данное правило диктовалось необходимостью четкой регламентации организации свиданий с содержащимися под стражей и обязывало посетителей являться в установленное законом время. В целом можно отметить прогрессивность предоставления арестантам возможности встреч с родственниками, поскольку семейные связи играют важную роль в исправительном процессе.

В конце 1860-х гг. остро встал вопрос о строительстве в Екатеринодаре войскового тюремного замка в связи с ростом численности населения Кубани и увеличением числа осужденных за преступления. В 1867 г. был утвержден проект тюрьмы, в котором архитектор учел новейшие достижения строительства пенитенциарных учреждений Европы. К сожалению, строительство, которое планировалось закончить к 15 октября 1871 г., растянулось почти на 10 лет, поскольку подрядчика купца Ф. К. Гельфонда отстранили от дальнейшего строительства за нарушение договора и работы были надолго приостановлены.

26 июня 1876 г. Екатеринодарская областная тюрьма была торжественно открыта. Территория тюрьмы, построенной из добротного кирпича, была разбита на секторы: заключенных переводили из одного сектора в другой по мере их исправления, при этом происходила «смена условий режима его содержания» [12, с. 185]. Следует отметить, что данный принцип нашел свое продолжение и в современной пенитенциарной системе. 
К началу 1880-х гг. в тюрьме, обнесенной «кирпичною стеною надлежащей высоты» (ГАКК. Ф. 454. Оп. 1. Д. 1388. Л. 2), насчитывалось «семь отделений, в том числе два двухэтажных кирпичных корпуса для содержания арестантов: первый - корпус общих арестантских палат из 27 комнат, второй для одиночных заключений на 60 камер, для женщин-заключенных предназначался кирпичный одноэтажный флигель. На территории тюрьмы располагались здание для размещения служащих, баня, прачечная» [9, c. 139].

Количество лиц, содержащихся в Екатеринодарской тюрьме, ежегодно увеличивалось. Согласно сведениям из отчета Кубанского областного правления за 1879 г. всего в тюрьме содержался 1171 чел. (ГАКК. Ф. 454. Оп. 1. Д. 1388. Л. 2 об.). В 1882 г. отбывали наказание уже 1195 чел., из них 858 - гражданские, 336 - казаки Кубанского казачьего войска. В 1885 г. из 1372 арестантов гражданских лиц было 984, а казаков 288 (ГАКК. Ф. 454. Оп. 2. Д. 96. Л. 21), что свидетельствует об преобладании среди арестантов гражданских лиц.

В феврале 1906 г. начальник Кубанской области принял решение о необходимости обследования условий содержания заключенных в Екатеринодарской тюрьме, для чего была создана специальная комиссия. Члены комиссии произвели осмотр жилых помещений и выявили, что практически во всех одиночных камерах размещено по несколько человек, в общих камерах также наблюдалось переполнение, на момент проверки в тюрьме находилось 580 арестантов. По результатам обследования комиссия пришла к выводам, что «необходимо уменьшить количество до 400 арестантов» (ГАКК. Ф. 583. Оп. 1. Д. 230-А. Л. 406).

Данные за 1906 г. содержали сведения о том, что в Екатеринодарской тюрьме, обслуживавшей не только город, но и станицы, села и аулы Екатеринодарского отдела, всего содержалось 2854 чел. По сословиям заключенные распределялись так: дворяне потомственные - 23 чел., дворяне личные 17 чел., купцы - 5 чел., мещане - 558 чел., крестьяне - 1635 чел., казаки Кубанского казачьего войска - 285 чел., военные - 5 чел., горцы - 161 чел., другие сословия - 148 чел. [12, с. 186].

В своих воспоминаниях участница революции 1905-1907 гг. на Кубани П. И. Вишнякова так описывала данную тюрьму: «тес- ная, чрезвычайно грязная, в особенности женская, с цементным полом, грязными стенами и полна клопов. Не были налажены, как в других тюрьмах, прогулки. Снабжение книгами отсутствовало. Пища подавалась в ржавых баках... В баню водили раз в два, а то и три месяца» [4, с. 286].

При Екатеринодарской войсковой тюрьме действовал лазарет на восемь мест, где арестантам оказывалась первая медицинская помощь. Местные войсковые лазареты, которых было в достаточном количестве в области, осуществляли лечение арестантов в случае их болезни. В августе 1909 г. было завершено строительство нового помещения больницы при Екатеринодарской областной тюрьме, после чего больные арестанты были переведены «во вновь выстроенные помещения» (ГАКК. Ф. 657. Оп. 1. Д. 1. Л. 46).

Вопросы расширения мест заключения Екатеринодара не утратили своей актуальности и в начале XX в. Так, в декабре 1908 г. по предложению начальника области во исполнение телеграммы Главного тюремного управления комиссией в составе областного инженера статского советника Кундухова, начальника второго отделения Кубанского областного правления статского советника Волошина и начальника Екатеринодарской областной тюрьмы Шпилевого с участием екатеринодаского купца Трахова было осмотрено место, на котором расположен арендуемый государством арестный дом, построенный бывшим начальником тюрьмы статским советником Скочко. Сделав соответствующие выводы, комиссия приняла решение о необходимости расширения арестного помещения на «свободной площади, вне тюремной ограды - на восток, между оградой стены и кирпичным заводом Кузнецова» путем «пристройки с обоих концов», поскольку расширить данное помещение иначе нельзя (ГАКК. Ф. 657. Оп. 1. Д. 1. Л. 28).

Результатом проверки стало заключение в декабре 1908 г. между Кубанским областным правлением и купцом Л. Н. Траховым договора о возведении пристройки к арендуемому государством у жены статского советника Е. И. Скачко помещения арестного дома для содержания арестантов. Договор содержал подробное описание объекта. Здание должно было состоять лишь из общих камер, без одиночных и карцеров. Общий размер здания в целом и отдель- 
ные камеры должны были соответствовать эскизу, утвержденному Главным тюремным управлением. Кроме того, две имеющиеся в арестном доме одиночные камеры должны были быть переоборудованы под комнату для свидания арестантов и туалет. Договором предусматривался порядок укладки кирпича, размеры, планируемые к использованию материалы и особенности их применения, особое внимание при этом уделялось обустройству окон, дверей, вентиляции. Согласно договору выстроенное здание подрядчик был обязан сдать в аренду Кубанскому областному правлению с взиманием арендной платы сроком на восемь лет, в течение которых он принимал на себя обязательства по наружному и внутреннему ремонту здания и побелке два раза в год (ГАКК. Ф. 657. Оп. 1. Д. 1. Л. 11). К слову, не только на Кубани, но и по всей России частные лица сдавали в наем помещения под тюремные учреждения. Примечательно, что выполнить подрядные работы по возведению данной пристройки также изъявлял желание инженер путей сообщения Б. Б. Шарданов, о чем он в письменном виде заявил начальнику Кубанской области. Однако сумма арендных платежей, предложенная Б. Б. Шардановым, а именно 4700 руб. в год, была значительно выше той, которую предложил купец Л. Н. Трахов - 3750 руб. в год (ГАКК. Ф. 657. Оп. 1. Д. 1. Л. 2). Данное обстоятельство свидетельствует о том, что лучшие условия исполнения контракта определялись по наименьшей стоимости, и позволяет сделать вывод о зарождении принципа обеспечения конкуренции, который имеет место в современной системе государственных закупок, в том числе и для уголовно-исполнительной системы.

По окончании работ в августе 1909 г. комиссией под председательством начальника 3-го отделения областного правления коллежского асессора Садило здание было принято к использованию. Арестанты там появились 1 сентября 1909 г. (ГАКК. Ф. 657. Оп. 1. Д. 1. Л. 48-50). Следует отметить, что по истечении восьмилетнего срока действия договора аренды здания, построенного на городской земле для содержания арестантов, в ноябре 1917 г. начальнику Кубанской области поступило представление Кубанского областного тюремного инспектора о необходимости «назначения комиссии для принятия от наследников умершего купца Л. Н. Трахова» (ГАКК. Ф. 657. Оп. 1. Д. 4. Л. 4).
Представляется, что тюремное ведомство тщательно следило за условиями исполнения обязательств по договорам, что является весьма актуальным для современной системы заключения контрактов.

Помещения Екатеринодарской областной тюрьмы постепенно продолжали расширяться. Так, в июле 1909 г. Главным тюремным управлением было согласовано строительство флигеля при Екатеринодарской областной тюрьме, а в сентябре представлен на утверждение план данного здания, разработанный при участии начальника тюрьмы. Согласно архивным документам построенный флигель был передан в аренду тюремному ведомству на восемь лет за плату по 7500 руб. в год, с дальнейшим переходом здания в собственность тюремного ведомства. При этом подрядчику, которым выступал екатеринодарский купец Л. Н. Трахов, было согласовано предоставление беспроцентной ссуды в размере 300 тыс. руб. из «штрафного капитала» Кубанской области (ГАКК. Ф. 657. Оп. 1. Д. 3. Л. 9, 14, 16).

Кроме того, в сентябре 1909 г. между Кубанским областным правлением и купцом Л. Н. Траховым был заключен договор о возведении на территории Екатеринодарской областной тюрьмы здания для содержания арестантов, размером в длину «тридцать девять пятьдесят сотых сажень» и в ширину «шесть семьдесят шесть сотых сажень» (ГАКК. Ф. 657. Оп. 1. Д. 2. Л. 31а). В договоре содержались обязательные условия относительно внешней и внутренней отделки помещений. Внешняя включала условия укладки кирпича: для фундамента и цоколя - в два с половиною кирпича, для наружных стен - в два кирпича, для внутренних стен - полтора кирпича. При этом кладка фундамента и цоколя в обязательном порядке необходима на цементе, стены - на извести и глине. Кроме того, чтобы избежать сырости, верхняя часть цоколя предусматривала асфальтовый слой толщиной полдюйма (около 13 мм). Внутренняя отделка предполагалась простая: двери и окна окрашены, потолки и стены оштукатурены и побелены известью, на окна с двойными оконными рамами в обязательном порядке установлены железные решетки, в печах и окнах - вентиляторы. В коридорах полы должны быть бетонными, в камерах - деревянными. Согласно договору построенное здание подрядчик должен был передать в 
аренду Кубанскому областному правлению на восемь лет с оплатою по 7500 руб. в год. Кроме того, на постройку данного здания л. Н. Трахову была выделена беспроцентная ссуда в размере 30 тыс. руб. (ГАКК. Ф. 657. Оп. 1. Д. 2. Л. 31 об).

В целях обеспечения надлежащего надзора в местах заключения значительное внимание уделялось вопросам укомплектования тюрем надзирателями для бдительного наблюдения за арестантами. Так, в июне 1910 г. начальник Екатеринодарской областной тюрьмы обратился в Кубанское областное правление с рапортом о необходимости увеличения штатной численности тюремной стражи на 15 чел. в связи с завершением строительства нового отделения тюрьмы и переводом туда арестантов. Объясняя потребность в укомплектовании, начальник тюрьмы, в частности, указывал, что пост на кухне будет состоять из двух человек, внутри здания требуются четыре поста по два человека, всего - восемь, со стороны стены, граничащей с кирпичным заводом, необходим наружный пост в количестве двух человек, кроме того, нужны два «выводных надзирателя» и один старший надзиратель. Также начальник тюрьмы просил о «высылке для упомянутых надзирателей вооружения, снаряжения и обмундирования» (ГАКК. Ф. 657. Оп. 1. Д. 3. Л. 37-38). В этом же месяце начальнику Кубанской области поступила подписанная начальником Главного тюремного управления Хрулевым телеграмма, в которой разрешалось принять 12 надзирателей с окладами одному в 360 руб., остальным - по 240 руб. (ГАКК. Ф. 657. Оп. 1. Д. З. Л. 40). Вскоре в дополнение к данной телеграмме Главное тюремное управление в письменном виде разъяснило, почему не находит возможности расширить штат еще на трех надзирателей для вновь устанавливаемого наружного поста со стороны кирпичного завода Кузнецова, указав, что наружная охрана мест заключения «лежит на обязанности восковых частей». В части материального обеспечения сотрудников тюрьмы пояснялось, что вопрос выделения средств будет решен после получения сведений об их найме, а об обеспечении вооружением и обмундированием руководство тюрьмы будет дополнительно уведомлено (ГАКК. Ф. 657. Оп. 1. Д. 3. Л. 41-41 об.). Резолюция начальника Кубанской области на данном документе содержала требование об установлении ограды со стороны кирпичного завода. В июле 1910 г. начальник тюрьмы отчитался перед Кубанским областным правление о том, что надзиратели приняты на работу, и ходатайствовал о «скорейшей высылке для надзирателей обмундирования, снаряжения и вооружения» (ГАКК. Ф. 657. Оп. 1. Д. 3. Л. 43).

Вопросы обустройства мест заключения наряду со строительством новых и расширением существующих учреждений не оставались без внимания со стороны государства. В августе 1910 г. Екатеринодарскую областную тюрьму посетили директора тюремного комитета С. Бейм, Х. Богарсуков, А. Коваленко, И. Горчаков и советник областного правления Г. Семенцов, которые внесли в книгу записей ряд замечаний, в частности такие: арестный дом, построенный Скочко, имеет плохую вентиляцию, в связи с чем необходимо «устроить хорошую»; в здании, построенном Траховым, необходимо сделать окна с откосами, раскрывающимися наружу, ванночки в камерах необходимо заменить «высокими кадочками на толстых ножках, внутри оцинкованными», в «клозете при больнице необходимо сделать высокие на цементе сидения», при это необходимо по стене сделать соответствующую вытяжку с выходом на крышу. Помимо повышенного внимания к соблюдению гигиенических требований (везде «спертый воздух») проверяющие обратили внимание на то, что в женском отделении "очень тесно», в связи с чем возникает необходимость строительства второго этажа. Результатом проверки явилось ходатайство членов комиссии начальнику Кубанской области о строительстве второго этажа над женским отделением (ГАКК. Ф. 657. Оп. 1. Д. З. Л. 45).

В 1912-1913 гг. на территории Екатеринодарской тюрьмы были построены дополнительно два новых корпуса. Это было обусловлено ростом населения Кубани, ухудшением криминогенной обстановки, нашедшим отражение в криминальной статистике за 1910-1912 годы [4, с. 346]. Поэтому «увеличивалось количество тех, кого необходимо было изолировать от общества» [12, с. 186].

К сожалению, начавшаяся Первая мировая война негативно отразилась на дальнейшем развитии пенитенциарных учреждений как в России в целом, так и на Кубани. 
Таким образом, развитие пенитенциарных учреждений в Кубанской области в целом и Екатеринодаре в частности происходило в период массового заселения пришлым населением, что не так характерно для других территорий и губерний Российской империи. С увеличением приезжего населения росло количество преступлений и лиц, отбывающих наказание в учреждениях тюремной системы. Приоритетными направлениями развития пенитенциарных учреждений Екатеринодара являлись следующие: расширение имеющихся и строительство новых помещений; обеспечение режима содержания заключенных; обеспечение бытовых условий арестантов; содействие нравственному исправлению; улучшение медицинского обслуживания арестантов и пр.

K началу XX в. тюремный комитет, в чьем ведении находились все пенитенциарные учреждения Кубани, сделал немало шагов в области тюремного попечительства по направлениям своей деятельности. Раз- витие попечительства по отношению к заключенным следует считать одним из механизмов, решавших задачу улучшения положения арестантов. Финансовой основой этой деятельности являлись казенные средства и поступающие в частном порядке благотворительные средства. Безусловно, пожертвования благотворителей делали жизнь арестантов легче.

Однако в пенитенциарных учреждениях Екатеринодара оставались нерешенными управленческие, материально-финансовые и иные проблемы, характерные для всей системы исполнения наказаний в виде лишения свободы рассматриваемого периода: недостаточное финансирование тюрем, переполненность тюремных зданий, а также неудовлетворительные условия содержания лиц, отбывающих наказание. Данное кризисное положение пенитенциарной системы в значительной мере было обусловлено общей социально-политической обстановкой в России начала XX в.

\section{СПИСОК ЛИТЕРАТУРЫ}

1. Батчаева, М. К. Деятельность российского «Общества попечительного о тюрьмах» во второй половине XIX - начале XX века (на материалах Ставрополья и Кубани) : автореферат диссертации на соискание ученой степени кандидата исторических наук / Батчаева Мария Касымовна. - Ставрополь, 2009. - 25 с.

2. Галкина, Н. И. Институт тюремного попечительства в Российской Империи и его особенности на Кубани : автореферат диссертации на соискание ученой степени кандидата юридических наук / Галкина Надежда Игоревна. Краснодар, 2009. - 30 c. - URL: https://kubsau.ru/upload/iblock/8c3/8c39e35854fa5423059963ffaea049e5.pdf (дата обращения: 01.09.2021)

3. Гернет, М. Н. История царской тюрьмы : в 5 томах / М. Н. Гернет. - Москва : Госюриздат, 1960-1963.

4. Екатеринодар-Краснодар: два века города в датах, событиях, воспоминаниях... Материалы к летописи / над книгой работали А. М. Авраменко и др. - Краснодар : Кн. изд-во, 1993. - 798 с. - ISBN 5-7561-0719-3.

5. Захаров, М. В. Эволюция российской пенитенциарной системы в условиях либеральных реформ 1861-1881 гг. : монография / М. В. Захаров, О. О. Спицына, А. Д. Лебедева. - Краснодар : ВЮИ ФСИН России, 2011. - 183 с. - ISBN 978-5-903317-25-7.

6. Краинский, Д. В. Материалы к исследованию истории русских тюрем в связи с историей учреждения Общества попечительного о тюрьмах / Д. В. Краинский. - Чернигов : Тип. Губ. зем., 1912. - 133 с.

7. Лобова, С. А. К вопросу о Екатеринодарском войсковом тюремном комитете / С. А. Лобова // Гуманитарные, социально-экономические и общественные науки. - 2015. - № 11-1. - С. 292-294.

8. Лобова, С. А. Становление и развитие пенитенциарной системы Кубани в конце XVIII в. - 1920-е годы (историкоправовое исследование) : автореферат диссертации на соискание ученой степени кандидата юридических наук / Лобова Светлана Александровна. - Краснодар, 2012. - 29 с.

9. Мартынова, Т. В. Развитие тюремной системы Кубани в первой половине XIXв. / Т. В. Мартынова // Вестник Владимирского юридического института. - 2006. - № 1. - С. 139-141.

10. Никитин, В. Н. Тюрьма и ссылка. Историческое, законодательное, административное и бытовое положение заключенных, пересыльных, их детей и освобожденных из под стражи, со времен возникновения русской тюрьмы до наших дней. 1560-1880 г. / В. Н. Никитин - Москва : Книга по требованию, 2011. - 665 с. - ISBN 978-5-4241-9708-6. 11. Основные административно-территориальные преобразования на Кубани (1793-1985 гг.) : справочник / составители А. С. Азаренкова и др. - Краснодар : Книжное изд-во, 1986. - 394 с.

12. Остапенко, П. И. История Екатеринодарской областной тюрьмы / П. И. Остапенко, И. В. Сирица // Вестник Владимирского юридического института. - 2007. - № 3 (4). - С. 184-187.

13. Печников, А. П. Тюремные учреждения российского государства (1649 - октябрь 1917 гг.) : историческая хроника / А. П. Печников. - Москва : Щит-М, 2004. - 324 с. - ISBN 5-93004-166-0.

14. Пионтковский, А. А. Тюрьмоведение, его предмет, содержание, задачи и значение / А. А. Пионтковский. - Одесса : Тип. Штаба Одес. воен. окр., 1892. - 16 с.

15. Познышев, С. В. Учение о карательных мерах и мере наказания : курс, составленный по лекциям / С. В. Познышев. - Москва : URSS, ЛЕНАНД, сор. 2016. - 181 с. - ISBN 978-5-9710-3078-2. 
16. Рассказов, Л. П. Лишение свободы в России: истоки, развитие, перспективы : монография / Л. П. Рассказов, И. В. Упоров. - Краснодар : КЮИ МВД России, 1999. - 490 с.

17. Рассказов, Л. П. Теория государства и права: углубленный курс : учебник / Л. П. Рассказов. - Москва : Инфра-М, 2015. - 559 с. - ISBN 978-5-16-010076-0.

18. Славинский, Н. В. Становление и развитие института тюремных инспекций Российской Империи и его специфика на Кубани : автореферат диссертации на соискание ученой степени кандидата юридических наук / Славинский Николай Васильевич. - Краснодар, 2009. - 27 с.

19. Таганцев, Н. С. Русское уголовное право : лекции : часть общая : [в 2 томах] / Н. С. Таганцев. - Москва : Наука, 1994. - ISBN 5-02-012940-2.

20. Упоров, И. В. Пенитенциарная политика России в XVIII- XX вв.: историко-правовой анализ тенденций / И. В. Упоров. - Санкт-Петербург : Юрид. центр Пресс, 2004. - 608 с. - ISBN 5-94201-340-3.

21. Фойницкий, И. Я. Учение о наказании в связи с тюрьмоведением / И. Я. Фойницкий. - Москва, 2000. - 462 с. ISBN 5-89391-061-3.

\section{REFERENCES}

1. Batchaeva M.K. Deyatel'nost' rossiiskogo "Obshchestva popechitel'nogo o tyur'makh» vo vtoroi polovine XIX nachale XX veka (na materialakh Stavropol'ya i Kubani): avto-referat dissertatsii na soiskanie uchenoi stepeni kandidata istoricheskikh nauk [Activity of the Russian "Prisons Custody Society" in the second half of the 19th - early 20th centuries (case study of Stavropol and the Kuban): Candidate of Sciences (History) dissertation abstract]. Stavropol, 2009. 25 p.

2. Galkina N. I. Institut tyuremnogo popechitel'stva v Rossiiskoi Imperii i ego osobennosti na Kubani: avtoreferat dissertatsii na soiskanie uchenoi stepeni kandidata yuridicheskikh nauk [The institute of prison guardianship in the Russian Empire and its features in the Kuban: Candidate of Sciences (Law) dissertation abstract]. Krasnodar, 2009. 30 p. Available at: https:// kubsau.ru/upload/iblock/8c3/8c39e35854fa5423059963ffaea049e5.pdf (accessed September 1, 2021).

3. Gernet M.N. Istoriya tsarskoi tyur'my : v 5 t. [History of the tsarist prison : in 5 vol.]. Moskow : Gosyurizdat, 1960-1963.

4. Ekaterinodar-Krasnodar: dva veka goroda v datakh, sobytiyakh, vospominaniyakh.... Materialy k letopisi [EkaterinodarKrasnodar: two centuries of the city in dates, events, memories.... Materials for the chronicle]., 1993. $800 \mathrm{p}$.

5. Zakharov M.V., Spitsyna O.O., Lebedeva A.D. Evolyutsiya rossiiskoi penitentsiarnoi sistemy v usloviyakh liberal'nykh reform 1861-1881 gg.: monografiya [Evolution of the Russian penitentiary system in the conditions of the 1861-1881 liberal reforms: monograph]. Krasnodar: Krasnodarskii filial Wul FSIN Rossii, 2011.183 p.

6. Krainskii D.V. Materialy $k$ issledovaniyu istorii russkikh tyurem $v$ svyazi $s$ istoriei uchrezhdeniya Obshchestva popechitel'nogo o tyur'makh [Materials for the study of the history of Russian prisons in connection with the history of the establishment of "Prisons Custody Society"]. Chernigov: tip. Gub. zem., 1912. 133 p.

7. Lobova S.A. On the question of the Ekaterinodar Military Prison Committee. Gumanitarnye, sotsial'no-ekonomicheskie i obshchestvennye nauki= Humanities, Social-economic and Social Science, 2015, no. 11-1, pp. 292-294. (In Russ.).

8. Lobova S.A. Stanovlenie i razvitie penitentsiarnoi sistemy Kubani v kontse XVIII v. - 1920-e gody (istoriko-pravovoe issledovanie): avtoreferat dissertatsii na soiskanie uchenoi stepeni kandidata yuridicheskikh nauk [Formation and development of the Kuban penitentiary system at the end of the 18th century - the 1920s (historical and legal research): Candidate of Sciences (Law) dissertation abstract]. Krasnodar, 2012. 29 p.

9. Martynova T.V. Development of the Kuban prison system in the first half of the 19th century. Vestnik Vladimirskogo yuridicheskogo instituta=Bulletin of Vladimir Law Institute, 2006, no. 1, pp. 139-141. (In Russ.).

10. Nikitin V.N. Tyur'ma i ssylka. Istoricheskoe, zakonodatel'noe, administra-tivnoe i bytovoe polozhenie zaklyuchennykh, peresyl'nykh, ikh detei i osvobozhdennykh iz pod strazhi, so vremen vozniknoveniya russkoi tyur'my do nashikh dnei. 1560-1880 g. [Prison and exile. Historical, legislative, administrative and living conditions of prisoners, prisoners in transit, their children and those released from custody, from the time of the emergence of the Russian prison to the present day. 1560-1880]. Moscow: Kniga po trebovaniyu, 2011. 665 p.

11. Osnovnye administrativno-territorial'nye preobrazovaniya na Kubani (1793-1985) [Key administrative-territorial transformations in the Kuban (1793-1985)]. Krasnodar: Kn. Izd-vo, 1986. 100 p.

12. Ostapenko P.I., Siritsa I.V. History of the Yekaterinodar regional prison. Vestnik Vladimirskogo yuridicheskogo instituta=Bulletin of Vladimir Law Institute, 2007, vol. 3, no. 4. 184-187. (In Russ.).

13. Pechnikov A.P. Tyuremnye uchrezhdeniya rossiiskogo gosudarstva (1649-oktyabr' 1917 gg.): istoricheskaya khronika [Prison institutions of the Russian state (1649 - October 1917): historical chronicle]. Moscow: Shchit-M, 2004. 324 p.

14. Piontkovskii A.A. Tyur'movedenie, ego predmet, soderzhanie, zadachi i znachenie [Prison studies, its subject, content, tasks and meaning]. Odessa: tip. Shtaba Odes. voen. okr., 1892. $16 \mathrm{p}$

15. Poznyshev S.V. Uchenie o karatel'nykh merakh i mere nakazaniya : kurs, sostavlennyi po lektsiyam [Doctrine of punitive measures and measure of punishment: a course compiled from lectures]. Moscow: URSS, LENAND, cop. 2016. 181 p. 16. Rasskazov L.P., Uporov I.V. Lishenie svobody v Rossii: istoki, razvitie, perspektivy: monografiya [Incarceration in Russia: origins, development, prospects: monograph]. Krasnodar: Krasnodarskii yuridicheskii institut MVD Rossii, 1999. 490 p. 17. Rasskazov L.P. Teoriya gosudarstva i prava: uglublennyi kurs: uchebnik [Theory of state and law: advanced course: textbook]. Moscow : Infra-M, 2015. 559 p.

18. Slavinskii N.V. Stanovlenie i razvitie instituta tyuremnykh inspektsii Ros-siiskoi Imperii i ego spetsifika na Kubani: avtoreferat dissertatsii na soiskanie uchenoi stepeni kandidata yuridicheskikh nauk [Formation and development of the Institute of Prison Inspections of the Russian Empire and its specifics in the Kuban : Candidate of Sciences (Law) dissertation abstract]. Krasnodar, 2009. 27 p.

19. Tagantsev N.S. Russkoe ugolovnoe pravo: lektsii: chast' obshchaya: $v 2 t$. [Russian Criminal Law: lectures: general part: in 2 vol.]. Compiled and edited by N.I. Zagorodnikov. Moscow: Nauka, 1994. 21 p.

20. Uporov I.V. Penitentsiarnaya politika Rossii v 18-20x vv.: istoriko-pravovoi analiz tendentsii [Penitentiary policy of Russia in the 18th-20th centuries: historical and legal analysis of trends]. Sankt-Petersburg: Yurid. tsentr Press, 2004. 608 p. 21. Foinitskii I.Ya. Uchenie o nakazanii v svyazi s tyur'movedeniem [The doctrine of punishment in connection with prison studies]. Moscow, 2000. 462 p. 


\section{СВЕДЕНИЯ ОБ АВТОРЕ / INFORMATION ABOUT THE AUTHOR}

ИРИНА ЛЕОНИДОВНА ИЗЮМСКАЯ - КаНДИДаТ ЮрИДИческих наук, старший инспектор по особым поручениям отдела гражданско-правовой, судебно-исковой и претензионной работы правового управления ФСИН России, г. Москва, Российская Федерация, ORCID: https:// orcid.org/0000-0002-8823-7592, e-mail: rochka1919@ rambler.ru
IRINA L. IZYUMSKAYA - Candidate of Sciences (Law), Senior Inspector for Special Assignments of the Department of Civil Law, Litigation and Claims Work of the Law Department of the Federal Penitentiary Service of Russia, Moscow, Russian Federation, ORCID: https:// orcid.org/0000-0002-8823-7592, e-mail: rochka 1919@rambler.ru 